\title{
Effects of Regional Trading Agreements on South Asian Trade: A Gravity Model Analysis
}

\author{
P. Dembatapitiya and J. Weerahewa ${ }^{1 *}$ \\ Postgraduate Institute of Agriculture \\ University of Peradeniya \\ Sri Lanka
}

\begin{abstract}
Regionalism in South Asia, through formation of regional and bilateral trading agreements, dates back to mid 1990s. The objective of this study is to assess the effects of various forms of trade agreements on bi-lateral trade of South Asia. Gravity model of international trade was used as the analytical tool and the effects of the World Trade Organization (WTO), Regional Trade Agreements (RTA) such as SAFTA, EU, ASEAN, BIMSTEC and NAFTA, and Bilateral Trade Agreements (BTA) were estimated. Three types of BTAs were included; between two South Asian countries, between a South Asian country and a country not in the region, and between two non-South Asian countries. Distance between the trading partners, sharing of common language, and colonial ties were the remaining explanatory variables included in the models. Cross sectional data covering 2555 bilateral trade for the year 2012 were used for the estimation and the data were extracted from the gravity databases of the Asia Pacific Research and Training Network, the World Bank and the WTO. The models were estimated using Ordinary Least Squares including importer and exporter fixed effects. The results of the estimation suggest that sharing of a common language, sharing a common colony, and membership of WTO positively and significantly affect export values and the effect of geographical distance, as expected, on the same has a negative effect. The memberships in BTA and RTA have mixed effects. Among RTAs used in the study, only the co-efficient for EU is statistically significant. SAFTA, ASEAN, BIMSTEC and NAFTA do not show significant effects on bilateral trade. The effects of all BTAs are positive and significant and they indicate that BTAs within South Asia enhance its regional trade greater than the BTAs with non-members. These results suggest that proliferation of BTAs within South Asia helped in expanding regional trade.
\end{abstract}

Keywords: BTA, gravity model, RTA, South Asia

\section{INTRODUCTION}

South Asia is known as one of the least integrated region in the world. Its major export destinations and import sources locate outside the region which comprise of developed countries and fast growing economies in East Asia. United State of America, United Arab Emirates and China are three main export destinations of South Asia while China, United Arab Emirates and Saudi Arabia are the three main import sources. However, South Asia occupies relatively a minor position in world trade. The region as a whole supplies only

\footnotetext{
1 Department of Agricultural Economics and Business Management, Faculty of Agriculture, University of Peradeniya, Peradeniya, Sri Lanka

Corresponding author: jeevikaw@gmail.com
} 
about 2 percent of world exports and contributes to 3 percent of world imports. South Asia's intra-regional trade remains less than 5 percent of its total trade (UN COMTRADE, 2012).

As in many other countries, South Asia also has been focusing on various trade arrangements since mid 1990s to secure and strengthen its trade relations. There was upsurge in formation of such agreements more recently. As the first intervention, many South Asian members entered into the World Trade Organization (WTO) in mid 1990s. Accordingly, Bangladesh, India, Maldives, Pakistan and Sri Lanka entered in 1995, Nepal entered in 2004 and Afghanistan and Bhutan are under negotiations currently. Thereafter, the members focused on establishing Regional Trading Agreements (RTAs) to enhance its trade. The first RTA of South Asia was South Asian Preferential Trade Agreement (SAPTA) and came into effect in 1995. South Asian member states moved to Bilateral Trade Agreements (BTA) in spite of SAPTA. At very first stages, South Asian countries entered to BTAs with regional members and later they formed BTAs with non-member states as well. At present, there are 14 BTAs and 2 RTAs are in-force in South Asia and it is notable that India is one party in 11 of BTAs (WTO database). Annex 1 Table 1 shows the evolution of different RTAs and BTAs in South Asia. and Annex 3 depicts noodle ball situation of trade in South Asia due to this increased interest in various trade agreements.

The above phenomena raises important question of whether intra or extra regional trade is more beneficial for South Asian countries. This will be helpful for policy makers in South Asia for future trade negotiations.

In history, trade agreements were more or less limited to geographical scope in the form of colonial influences or bilateral commercial treaties. Provision of GATT agreement in 1947 was the foundation for an expanding multilateral trade system and it was the basis for modern WTO agreement. However, GATT did not diminish the attraction towards different bilateral and regional trade relations. In the mid-nineteenth century, the first major phase of regionalism recorded with creation of European Union (EU). It has been at the center of successive wave of regionalism and later on North America and Asia have also joined with that trading system. Similarly, many developing countries in Africa, Caribbean, Central and South America followed that regional trading system (WTO, 2011).

RTAs provide opportunity for group of countries to negotiate rules and commitments to strengthen their trade relations. However, recently, many countries have focused on various BTAs as well to strengthen their country's trade. The effects of such trade arrangements have been assessed using various techniques and among them gravity model of international trade has been widely used.

Tinbergen (1962) provided initial specification for the gravity model which uses to analyze determinants of trade flows. Aitken (1973) applied this approach to analyze the effects of Preferential Trade Agreements (PTAs) on trade flows of its member countries. It introduced a variable which take the value of one if two trading partners are members of a PTA and zero otherwise. The positive and statistically significant coefficient of the model indicated that PTA increases trade at significant level within its member states.

Muhammad and Yucer (2010) analyzed trade creation and diversion effects of RTAs using a gravity estimation. Trade creation occurs when introduction of a RTA allows supply from a more efficient producer of the product and trade diversion occurs when RTA divert trade away from more efficient supplier outside the region, towards a supplier within the region. The study had used six RTA dummy variables covering 30 countries and results evidenced 
for greater trade creation from RTAs except North American Free Trade Agreement (NAFTA). NAFTA and Southern Common Market (MERCOSUR) were shown significant trade diversion effect.

Bayoumi and Eichengreen (1997) assessed the impacts of regionalism on Europian trade using a gravity model. The results were shown that the formation of Europe Economic Community (EEC) and European Free Trade Association (EFTA) had significant impact on Europe's trade and EFTA is heavily trade creating. EEC promoted intra-bloc trade through combination of both trade creation and trade diversion. EEC increased trade between its members at significant level but reduced trade with rest of the world significantly.

Korinek and Melatos (2009) analyzed the effects of three RTAs (i) ASEAN Free Trade Agreement (AFTA) (ii) Common Market for Eastern and South Africa (COMESA) and (iii) MERCOSUR on agricultural trade using a gravity model. The results suggest that AFTA, COMESA and MERCOSUR have increased trade in agricultural products between its member countries significantly and the agreements were net trade creating. The depth of integration within the agreement is important in determining the extent to which it is trade creating. Trade cost remains as important determinant of agriculture trade flows of those member states. Furthermore, historical trade pattern and traditional economic ties are also important determinants of trade flows. It also highlights the fact that RTA creates free trade among member countries, but it does not guarantee welfare improvements either for members and non-members.

Clarete et al. (2002) also did similar econometric study for Asia using panel data for the period 1980 to 2000 . The results indicated that conventional gravity variables, i.e., size of economies, distance, geographical area and sharing a common border, were statistically significant at 0.05 probability level. Distance between the two countries was the most important basic determinant of trade flows in Asia. The analysis proved that trade agreements of Economic Cooperation Organization (ECO), EFTA, MERCOSUR, SAPTA and South Pacific Regional Trade and Economic Cooperation Agreement (SPARTECA) generate strong positive intra bloc trade effects and it led member states to divert their trade towards its regional members. Asia-Pacific Economic Cooperation (APEC) creates statistically significant trade flows among its members as well as rest of the world. However, EU showed negative and statistically significant results on its intra-bloc trade for the years of 1980 and 1985 and insignificant results for both 1995 and 2000. Estimates of AFTA and NAFTA did not show significant effects on intra bloc trade but reduced trade with both members and rest of the world. Clarete et al. (2002) suggest that APEC, ECO and MERCOSUR appeared to be having the greatest impacts on intra bloc trade and AFTA and NAFTA have reduced trade with their members during the study period.

The general objective of the study was to assess the various forms of regional trading agreements on bilateral trade of South Asia. The specific objectives are:

1. To assess the effects of WTO, RTA, BTA on bilateral trade of South Asia

2. To assess the effects of Regional Trading Agreements; SAFTA, EU, ASEAN, BIMSTEC and NAFTA on bilateral trade flows

3. To assess the effects of three types of BTAs, i.e., BTAs with two South Asian countries, between a South Asian country and a country not in the region and two non-South Asian countries on bilateral trade 


\section{MODEL AND DATA}

Starting with Tinbergen (1962), gravity model has become the key tool of applied international trade literature. It allows an ex-post analysis of trade and links trade flow between two countries, directly with economic size and inversely with trade cost, usually proxied by geographical distance which is an indicator of transport cost. Gravity model was initially presented by Tinbergen (1962) as intuitive way as follows.

$$
\log \mathrm{X}_{11}=c+\beta_{1} \log G D P_{i}+\beta_{2} \log G D P_{j}+\beta_{3} \log D_{i}+\varepsilon_{i}
$$

Where,

$\begin{array}{lll}\mathrm{X}_{\mathrm{ij}} & = & \text { Value of exports from } \mathrm{i}^{\text {th }} \text { country to } \mathrm{j}^{\text {th }} \text { country } \\ \mathrm{GDP}_{\mathrm{i}} & =\text { Gross Domestic Product of } \mathrm{i}^{\text {th }} \text { exporting country } \\ \mathrm{GDP}_{\mathrm{j}} & =\text { Gross Domestic Product of } \mathrm{j}^{\text {th }} \text { importing country } \\ \mathrm{D}_{\mathrm{ij}} & = & \text { Distance between } \mathrm{i}^{\text {th }} \text { exporting country and } \mathrm{j}^{\text {th }} \text { importing country } \\ \boldsymbol{\varepsilon}_{\mathrm{ij}} & = & \text { Random error }\end{array}$

It hypothesizes larger country pair trade more but countries that far away from each other trade less due to high transport cost (Shepherd, 2012). The intuitive gravity model also typically includes indication of common language and culture, historical ties to explain trade pattern (Kowalski and Shepherd, 2006). Later literature evidenced for addition of dummy variables to capture the effects of RTAs on trade flows.

This study assesses the effects of WTO, RTAs and BTAs using institutive gravity model following Aitken (1973), Bayoumi and Eichengreen (1997), and Clarete et al. (2002). Log of export value was treated as the dependent variable and conventional gravity variables such as size of economies, distance between two trading partners, dummy variable for colonial ties, sharing common language and policy variables of membership in WTO, RTAs and BTAs were considered as the determinants of value of exports.

Dummy variables for importer and exporter country fixed effects were included to account all possible cultural, historical and other factors that influence on trade. Two gravity models were specified as follows:

$$
\begin{gathered}
\log X_{1 j}=\beta_{0}+\beta_{1} \log G D P_{1}+\beta_{2} \log G D P_{1}+\beta_{3} \log D_{10}+\beta_{4} \operatorname{CLAN}+\beta_{5} \operatorname{CCOL}+\beta_{6} \text { WTO } \\
+\beta_{7} \text { RTA }+\beta_{8} \text { BTA }+\varepsilon_{11}
\end{gathered}
$$

Where,

WTO $=$ Membership in WTO: $\mathrm{WTO}=1$ if both countries are WTO members and zero otherwise

RTA $=$ Membership in RTAs: RTA $=1$ if both countries are members of same RTA and zero otherwise

BTA $=$ Membership in BTAs: $\mathrm{BTA}=1$ if both countries are members of same BTA and zero otherwise

CLAN $=$ Dummy variable for sharing common official language: CLAN=1 if both trading partners share common official language and zero otherwise

$\mathrm{CCOL}=$ Dummy variable for colonial ties: $\mathrm{CCOL}=1$ if both trading partners are in same colony and zero otherwise

$\varepsilon_{\mathrm{ij}} \quad=$ Random error 


$$
\begin{aligned}
\log X_{1]}=\beta_{0}+\beta_{1} & \log D_{11}+\beta_{2} \text { CLAN }+\beta_{3} \text { CCOL }+\beta_{4} \text { SAFTA }+\beta_{5} \text { EU }+\beta_{6} \text { ASEAN } \\
& +\beta_{7} \text { BIMSTEC }+\beta_{8} \text { NAFTA }+\beta_{5} \text { BTA }_{1}+\beta_{10} \text { BTA }_{2}+\beta_{11} \text { BTA }_{3} \\
& +\varepsilon_{11}
\end{aligned}
$$

Where,

SAFTA, EU, ASEAN, BIMSTEC and NAFTA dummy variables were treated as different RTAs which take the value of one if two trading partners are members in the same RTA, and zero otherwise.

BTA $_{1}=\quad \begin{aligned} & \text { BTA between two regional members: BTA1=1 when presence of BTA } \\ & \text { between two South Asian members and zero otherwise }\end{aligned}$
BTA $_{2}=\begin{aligned} & \text { BTA between a South Asian member and a non member: BTA2 }=1 \text { when } \\ & \text { presence of BTA between South Asian member and a country not in South }\end{aligned}$
BTA $_{3}=\begin{aligned} & \text { Asia, and zero otherwise } \\ & \text { BTA between two regional non members: BTA3=1 when presence of BTA } \\ & \text { between two non South Asian members and zero otherwise }\end{aligned}$

Cross sectional data covering 2555 bilateral trade for the year 2012 were used for the estimation and the data were extracted from the gravity databases of Asia Pacific Research and Training Network, the World Bank and WTO database. The models were estimated using Ordinary Least Squares. Hetero-scedasticity issue was corrected using robust standard error correction method. Multi-colinearity among variables was analyzed using Variance Inflation Factor (VIF) estimation.

GDP variables were not used in fixed effects estimations due to the assumption that variables which vary in the same dimension as fixed effects cannot be included in fixed effects model.

\section{RESULTS AND DISCUSSION}

\section{Descriptive statistics of sample}

Out of 2555 country pairs, 80.3 percent represents trade flows between two WTO members, 20 percent represents bilateral trade between two members in same RTA and 8.3 percent symbolizes trade flows between two parties of any type of BTA. Bilateral trade between members in European Union accounts 9.4 percent of total observations, while ASEAN, NAFTA, SAFTA and BIMSTEC records 1.5, 0.2, 0.6 and 0.5 percentages respectively.

As indicated earlier, two sets of estimation were proceeded to estimate the effects of WTO, RTA and BTA on both world exports and South Asian exports. The purpose of proceeding two sets of estimation is to analyze the determinants of trade flows of South Asia, in comparison with determinants of world exports. A sample of South Asian exports was driven from the primary sample of world exports. It includes bilateral trade flows of South Asian countries with both regional members and non members. South Asian exports sample accounts 16.9 percent of observations in the world export sample. Table 1 shows the descriptive statistics on size of economies, value of exports and geographical distance. 
Table 1. Descriptive statistics of variables used for the estimation

\begin{tabular}{lllll}
\hline \multirow{2}{*}{ Variable } & \multicolumn{2}{c}{ World exports } & \multicolumn{2}{c}{ South Asian exports } \\
\cline { 2 - 5 } & Mean & St.Err & Mean & St.Err \\
\hline Value of exports (US \$) & $1.31 * 10^{10}$ & $0.40^{*} 10^{10}$ & $3.22^{*} 10^{8}$ & $1.59 * 10^{8}$ \\
Exporter GDP (US \$) & $1.71 * 10^{11}$ & $0.14 * 10^{11}$ & $0.96^{*} 10^{11}$ & $0.26^{*} 10^{11}$ \\
Importer GDP (US \$) & $1.12^{*} 10^{11}$ & $0.12 * 10^{11}$ & $0.64 * 10^{11}$ & $0.21 * 10^{11}$ \\
Distance (Km) & $3.8 * 10^{6}$ & 0.0104 & $4.36^{*} 10^{6}$ & 0.0105 \\
Number of country pairs & 2555 & & 431 & \\
\hline
\end{tabular}

Table 1 clearly shows that size of economies of South Asian members is less than the world average, reflecting those member states are still developing countries. It also indicates countries with smaller economies imports goods from larger economies. The average distance between two South Asian countries is greater than world average.

\section{Effects of WTO, RTA and BTA on trade flows}

As mentioned earlier, two sets of gravity model estimations were done to assess the effects of both multilateral and regional trading agreements on world exports as well as South Asian exports. Each analysis was done with and without fixed effects. The V.I.F. analysis was done to examine the correlation among the variables used in gravity model estimation. It shows how much the variance of the coefficient estimated is being inflated due to multicolinearity $^{2}$. As a rule of thumb, if V.I.F. values greater than 10 , there might be multicolinearity issue. Annex 2 Table 1 shows the V.I.F. values for the variables used in econometric estimations. Accordingly, WTO and common colony variables are omitted in fixed effect estimations due to high multi-colinearity.

Given F-statistics for overall significance of the model, all estimations are significant at 0.001 probability levels. As per the results of econometric estimation, size of the economies in two trading partners is positive and significant determinant of world exports as well as South Asia. Geographical distance has negative and significant effects on bilateral trade in both cases. It is noteworthy that the R-square values of fixed effects estimations are greater than the R-square values of estimations without fixed effects. Thus model with fixed effect estimation is treated as the accepted model estimation for this study. Table 2 shows results of the Estimation of Gravity Model depicting the Effects of WTO, RTA and BTA on Bilateral Trade Flows.

In the results of fixed effect estimations, model for world exports records $0.84 \mathrm{R}$-square value while for South Asian exports model it is 0.86. Among the conventional gravity variables, geographical distance, sharing of common language, common colony are significant in world exports model at 0.001 probability level whereas only the geographical distance is significant in South Asian exports. The memberships in RTA and BTA are significant determinants of world exports while it does not create any significant effects on South Asian exports at aggregate level. Memberships in WTO is also a positive determinant of world exports as well as South Asia in without fixed effect estimation, but it was omitted in fixed effect model due to the multi-colinearity issue.

\footnotetext{
${ }^{2}$ The square root of V.I.F. value shows how much larger the standard error compared with what it would be if variables are uncorrelated. For example if V.I.F. is 4 the standard errors are 2 times greater than it would be.
} 
Table 2. Results of the Estimation of Gravity Model depicting the Effects of WTO, RTA and BTA on Bilateral Trade Flows

\begin{tabular}{|c|c|c|c|c|}
\hline \multirow{2}{*}{$\begin{array}{c}\text { Independent } \\
\text { variable }\end{array}$} & \multicolumn{2}{|c|}{ World exports } & \multicolumn{2}{|c|}{ South Asian exports } \\
\hline & $\begin{array}{c}\text { Without } \\
\text { fixed effects }\end{array}$ & With fixed effects & $\begin{array}{c}\text { Without } \\
\text { fixed effects }\end{array}$ & $\begin{array}{c}\text { With fixed } \\
\text { effects }\end{array}$ \\
\hline Constant & $\begin{array}{c}0.622 \\
(0.455)\end{array}$ & $\begin{array}{c}0.254 \\
(0.905)\end{array}$ & $\begin{array}{l}-3.224 \\
(1.498)\end{array}$ & $\begin{array}{l}-0.824 \\
(4.031)\end{array}$ \\
\hline ln exporter GDP & $\begin{array}{c}1.239 * * * \\
(0.022)\end{array}$ & & $\begin{array}{c}1.192 * * * \\
(0.049)\end{array}$ & \\
\hline In importer GDP & $\begin{array}{c}0.971 * * * \\
(0.017)\end{array}$ & & $\begin{array}{c}0.964 * * * \\
(0.042)\end{array}$ & \\
\hline In distance & $\begin{array}{c}-1.087 * * * \\
(0.050)\end{array}$ & $\begin{array}{c}-1.301 * * * \\
(0.566)\end{array}$ & $\begin{array}{c}-0.700 * * * \\
(0.178)\end{array}$ & $\begin{array}{c}-1.043 * * \\
(0.450)\end{array}$ \\
\hline Common language & $\begin{array}{c}0.619 * * * \\
(0.134)\end{array}$ & $\begin{array}{c}0.621 * * * \\
(0.134)\end{array}$ & $\begin{array}{c}0.288 \\
(0.300)\end{array}$ & $\begin{array}{c}0.122 \\
(0.293)\end{array}$ \\
\hline Common colony & $\begin{array}{c}0.473 * * \\
(0.221)\end{array}$ & $\begin{array}{c}0.693 * * * \\
(0.194)\end{array}$ & $\begin{array}{c}0.859 \\
(0.664)\end{array}$ & \\
\hline WTO & $\begin{array}{c}0.573 * * * \\
(0.103)\end{array}$ & & $\begin{array}{c}1.220 * * * \\
(0.335)\end{array}$ & \\
\hline RTA & $\begin{array}{c}0.880 * * * \\
(0.118)\end{array}$ & $\begin{array}{c}0.291 * * \\
(0.094)\end{array}$ & $\begin{array}{c}1.034 * * * \\
(0.269)\end{array}$ & $\begin{array}{c}0.184 \\
(0.404)\end{array}$ \\
\hline BTA & $\begin{array}{c}0.882 * * * \\
(0.144)\end{array}$ & $\begin{array}{c}0.782 * * * \\
(0.106)\end{array}$ & $\begin{array}{c}0.664 \\
(0.428)\end{array}$ & $\begin{array}{c}0.418 \\
(0.312)\end{array}$ \\
\hline F-value & 931.06 & 108.14 & 139.49 & 23.06 \\
\hline $\mathrm{R}^{2}$ value & 0.74 & 0.84 & 0.72 & 0.86 \\
\hline Mean VIF & 1.15 & 2.95 & 1.16 & 7.09 \\
\hline No of observations & & 2555 & & \\
\hline $\begin{array}{ll}* * * & \text { Significant at } 0.001 \\
* * & \text { Significant at } 0.05 \mathrm{p} \\
* & \text { Significant at } 0.1 \mathrm{pr} \\
& \text { Standard Frror }\end{array}$ & $\begin{array}{l}\text { ility level } \\
\text { lity level } \\
\text { ty level } \\
\text { in narenth }\end{array}$ & & & \\
\hline
\end{tabular}

Geographical distance negatively affects on value of exports both in world as a whole and South Asia. One percent increase in distance between two trading partners decreases world exports by 1.30 percent and for South Asian exports it is by 1.04 percent. It is the only determinant of trade flows in South Asia according to the estimated results. The sharing common official language and common colony increase value of world exports significantly. Trade between two countries with same official language increase value of world exports by $4178 \mathrm{US}^{3}$ with compared to the situation of existing different official languages between two countries. Being trading partners with same colonial influence increases world exports by 4931 US $\$$ in comparison with trading partners with different colonial powers.

Memberships in RTA and BTA also increase world exports at significant level. The RTAs increase value of world exports by 1954 US\$ while in case of a BTA it is 6053 US\$. It is notable that membership in BTA increases value of exports, greater than the value when there is membership in RTA. That value is also larger than the increased value of world

\footnotetext{
${ }^{3}$ All the values which explains the changes in value of exports due to dummy variables were taken from antilog of the relevant coefficient
} 
exports due to other significant determinants of trade. Thus it can be concluded that BTA is the most important determinant of value of exports in world, according to the results of the study.

\section{Effects of different types of RTAs and BTAs on trade flows}

Given the F-statistics of overall significance of the model, estimated model is significant at 0.001 probability level with 0.84 R-squared values. The results of the Estimation of Gravity Model depicting the Effects of different RTAs and BTAs on Bilateral Trade Flows are shown in table 3 below.

Table 3. Results of the Estimation of Gravity Model depicting the Effects of different RTAs and BTAs on Bilateral Trade Flows

\begin{tabular}{lcc}
\hline \multicolumn{1}{c}{ Independent variable } & \multicolumn{2}{c}{ World exports } \\
\hline & Coefficient & St.Err. \\
Constant & 2.069 & 0.929 \\
ln distance & $-1.449^{* * *}$ & 0.063 \\
Common language & $0.624^{* * *}$ & 0.136 \\
Common Colony & $0.631^{* * *}$ & 0.197 \\
BTA between two South Asian countries & $1.316^{* *}$ & 0.666 \\
BTA between a South Asian member and a non & $0.562^{* * *}$ & 0.182 \\
member & & \\
BTA between two South Asian non members & $0.730^{* * *}$ & 0.123 \\
SAFTA & 0.772 & 0.604 \\
EU & $-0.489 * *$ & 0.163 \\
ASEAN & 0.137 & 0.237 \\
BIMSTEC & -0.256 & 0.351 \\
NAFTA & 0.145 & 0.751 \\
F-statistics & 103.47 & \\
Mean VIF & & 2.82 \\
No of observations & \multicolumn{2}{c}{2555} \\
\hline$* *$ Significant at 0.001 probability level & & \\
$* *$ Significant at 0.05 probability level & & \\
Significant at 0.1 probability level & &
\end{tabular}

Similarly the previous estimation results, geographical distance, sharing of common language and colonial ties show significant effects on value of world exports at 0.001 probability level. Accordingly, this estimation also evidences that one percent increase in distance between two trading partners decreases the value of world exports by 1.4 percent which is closer to the previous estimated result of 1.3 percent. Country pairs sharing with common official language and common colony increases value of exports by 4207 US\$ and 4275 US\$ respectively.

Considering the effects of different RTAs used in the estimation, only EU create significant effects on trade flows while SAFTA, ASEAN, BIMSTEC and NAFTA do not create any significant effects. The negative and significant coefficient of EU suggest that regionalization through the formation European Union was not good for its member countries in 2012. According to the results of the estimation, the membership in EU 
decreases value of exports in world by 3083 US\$. Europe was faced with a financial crisis during recent past and because of that many financial institutions in Europe zone were undercapitalized. As a result, economic growth of Europe declined and it unequally distributed across its member states (Dabrowski, 2010). In such a situation regionalization generate negative and significant effects on trade. However European countries made positive and statistically significant effects on value of world exports individually (See Annex 2 Table 2). Achieving negative and significant coefficient for intra bloc trade and positive and significant coefficients for its overall trade demonstrates, though intra regional trade was disadvantages for European members during the period of study, continuing its overall trade with both intra and extra bloc countries increase its trade at significant level. Clarete et al. (2002) showed similar results for EU and indicated that intra-bloc exports of EU were negative and significant for the years of 1980 as well as 1985, and for 1990 it was negative in sign but not significant. During 1995 and 2000 it was positive in sign but not significant too. However the overall exports and imports of European members were significant, across all the above mentioned years with positive sign.

Following the same results of Clarete et al. (2002), NAFTA shows positive effects on its intra-bloc trade, but it is not significant. ASEAN is the same and BIMSTEC shows negative effects on value of exports, but it is also not significant. SAFTA is not a significant determinant of world exports, indicating that the failures in achieving its regional trade expectations.

All three types of BTAs; between two South Asian members, between a South Asian member and a country not in South Asia and between two regional non members, are positive and significant determinants of bilateral trade in world. BTAs within South Asian region are statistically significant at 0.05 probability level and it increases world exports by 20701 US\$, compared to the situation of none existence of a BTA between two countries. The BTAs between a regional member and a non member increase world exports by 3647 US\$ and it is also statistically significant at 0.05 probability level. Existence of BTAs between two regional non members, increase world exports by 5370 US\$ at significant level. It is noteworthy that though South Asia failed to achieve its trade expectations through SAFTA, it is capable in expanding regional trade through formation of BTAs with both regional members and non members. Furthermore, BTAs within South Asian region increase value of exports than the value, when there is a BTA with a non member.

Overall results of the analysis suggest that BTAs have mix effects on South Asian trade. They show insignificant results at aggregate level but when it considers BTAs separately, they show positive and significant results. However the study has proven that, among RTAs and both intra and extra-bloc BTAs, the BTA arrangements within the region is the best policy option for South Asia to enhance its regional trade at greater extend.

\section{CONCLUSIONS}

Size of the economies, sharing common official language and colonial ties are positive and significant determinants of value of exports in world as well as in South Asia. Distance has negative and significant effects. RTAs and BTAs as a whole have positive and significant effects on world exports but not on South Asian exports. Among different RTAs used in the study, only EU has significant effects on exports while SAFTA, ASEAN, BIMSTEC and NAFTA unable to create any significant effects on it. However EU negatively affected on its intra-bloc exports during the period of study. Since this has done for the year 2012, European 
financial crisis may cause for such a negative results. Along with different types of BTAs, entering of BTAs with both regional members and non members create positive and significant effects on South Asian exports. It is notable that value of increase in exports due to the BTAs within South Asian region is greater than the values of BTAs with extra bloc economies.

Though SAFTA failed to create significant increase in regional trade of South Asia, BTAs within the region enhance its trade at significant level. Thus the study evidences for proliferations of BTAs within the region are advantage for South Asia as it enhances regional trade at greater extent.

\section{REFERENCES}

Aitken, N.D. (1973). The effect of EEC and EFTA on European trade: A temporal cross sectional analysis. American Economic Review, 63, pp. 881 - 892.

Baldwin, R.E. (1994). A domino theory of Regionalism. Graduate Institute of International Studies, University of Geneva.

Bayoumi, T. and Eichengreen, B. (1997). Is Regionalism simply a diversion? Evidence from the evolution of EC and EFTA. National Bureau of Economic Research, 6, $141-168$.

Cipollina, M. and Salvatici, L. (2007). Reciprocal Trade Agreements in gravity model: A meta-analysis. Economics and Statistics discussion paper, 35. University of Molise.

Clarete, R., Edmonds, C. and Wallack, J.S.(2002). Asian Regionalism and its Effects on Trade in 1980s and 1990s. Working paper series, 30. Asian Development Bank.

Dabrowski, M. (2010). The global financial crisis: Lessons for European Integration. Economic Systems, 34(1).

Deardorff, A. (1998). Determinants of bilateral trade: Does gravity works in neoclassical world. The regionalization of the world economy. University of Chicago press, 7-32.

Frankel, J.A., Romer, D. (1999). Does trade cause growth. The American Economic Review, 89(3), 379 - 399.

Frankel, J.A. and Wei, S.J. (1997). Regionalization of World Trade and currencies: Economics and Politics. The Regionalization of the World Economy. University of Chicago press.

Korinek, j. and Melatos, M. (2009). Trade impacts of selected Regional Trade Agreements in Agriculture. OECD Trade Policy Working Papers, 87, OECD publishing.

Kowalski, P. and Shepherd, B. (2006). Economic perspective on Development Issues in the Multilateral Trading System. OECD Trade Policy Studies, OECD.

Muhammad, K. and Yucer, A. (2010). Impact of Regional Trade Agreements: Trade creation and trade diversion in Western Hemisphere. International Journal of Economic Issues, 3(2), $221-238$.

Park, I. (2006). East Asian Regional Trade Agreements: Do they promote global Free Trade. Paper presented at Korea vs world economy conference, Korea University, Seoul, Korea. 
Shepherd, B. (2012). The Gravity model of International Trade. United Nations Economic and Social Commission for Asia and the Pacific. United Nations Publication, Thailand.

Tinbergen, J. (1962). Shaping the World Economy: Suggestions for an International Economic Policy, New York.

Tumbarello, P. (2007). Are Regional Trade Agreements in Asia stumbling or building blocs. Implication for Mekong-3 Countries.Working paper, 53. International Monetary Fund.

World Trade Organization. (2011). The WTO and Preferential Trade Agreements: From coexistence to coherence, World Trade Report. 
ANNEX 01

Table 1. Evolution of Regional Trading Agreements in South Asia

\begin{tabular}{|c|c|c|c|c|c|c|}
\hline & $\begin{array}{c}\text { Trade } \\
\text { Agreement }\end{array}$ & $\begin{array}{l}\text { Member } \\
\text { Countries }\end{array}$ & $\begin{array}{l}\text { Entry into } \\
\text { force }\end{array}$ & Type & Coverage & Primary objectives and concessions \\
\hline 01 & $\begin{array}{l}\text { South Asian } \\
\text { Preferential } \\
\text { Trade } \\
\text { Agreement } \\
\text { (SAPTA) }\end{array}$ & $\begin{array}{l}\text { Bangladesh, } \\
\text { Bhutan, India, } \\
\text { Maldives, Nepal, } \\
\text { Pakistan, } \\
\text { Lanka }\end{array}$ & $\begin{array}{l}\text { 11-April- } \\
1993\end{array}$ & PSA & Goods & $\begin{array}{l}\text { Concessions were given to contracting states partially and promoted } \\
\text { trade in goods in South Asian region. Afghanistan was not a } \\
\text { contracting party of this agreement. It was replaced by SAFTA in } \\
2006 \text {. }\end{array}$ \\
\hline 02 & $\begin{array}{l}\text { India Sri } \\
\text { Lanka Free } \\
\text { Trade } \\
\text { Agreement }\end{array}$ & India, Sri Lanka & 15-Dec-2001 & FTA & Goods & $\begin{array}{l}\text { Promote harmonious development of two economies by expanding } \\
\text { trade. Mutually beneficial bilateral trade. Elimination of tariffs. Each } \\
\text { country is allowed to take action and adapting measures to protect its } \\
\text { nation. }\end{array}$ \\
\hline 03 & $\begin{array}{l}\text { India } \\
\text { Afghanistan }\end{array}$ & $\begin{array}{l}\text { India, } \\
\text { Afghanistan }\end{array}$ & $\begin{array}{l}\text { 13-May- } \\
2003\end{array}$ & PSA & Goods & $\begin{array}{l}\text { It expands domestic markets of two countries through economic } \\
\text { integration and eliminates trade barriers through preferential } \\
\text { treatment. Afghanistan concerns the preferential tariff for black tea, } \\
\text { medicinal goods, Sugar refined and Cement. India concerns about } \\
\text { raisins, Apricots, Pistachios, Walnuts, plumb, Almond, Mulberries, } \\
\text { Pine nuts, Cherry, Melon etc. }\end{array}$ \\
\hline 04 & $\begin{array}{l}\text { Bay of Bengal } \\
\text { Initiative for } \\
\text { Multi- } \\
\text { Sectoral } \\
\text { Technical and } \\
\text { Economic } \\
\text { Cooperation } \\
\text { (BIMSTEC) }\end{array}$ & $\begin{array}{l}\text { Bangladesh, } \\
\text { India, Myanmar, } \\
\text { Sri Lanka, } \\
\text { Thailand, Bhutan, } \\
\text { Nepal }\end{array}$ & 08-Feb-2004 & FTA & $\begin{array}{l}\text { Goods, } \\
\text { service } \\
\text { and } \\
\text { investmen } \\
\mathrm{t}\end{array}$ & $\begin{array}{l}\text { It involves in linking two major regional groups; ASEAN and } \\
\text { SAARC. It provides two track tariff reduction/elimination programs; } \\
\text { (i) Fast track (ii) Normal track, liberalization of trade in services and } \\
\text { investment and cooperation in identified sectors. It specified different } \\
\text { timing commitments for least developed countries (LDC) and non- } \\
\text { least developed countries. For normal track products, non-LDCs } \\
\text { agreed to eliminate tariff for LDCs by } 2010 \text { and tariff among } \\
\text { themselves by 2012. LDCs eliminate tariff among themselves by } 2015 \\
\text { and for other BIMSTEC members by } 2017 \text {. }\end{array}$ \\
\hline 05 & $\begin{array}{l}\text { Pakistan Sri } \\
\text { Lanka Free } \\
\text { Trade } \\
\text { Agreement }\end{array}$ & $\begin{array}{l}\text { Pakistan, } \\
\text { Lanka }\end{array}$ & $\begin{array}{l}\text { 12-June- } \\
2005\end{array}$ & FTA & $\begin{array}{l}\text { Goods } \\
\text { and } \\
\text { services }\end{array}$ & $\begin{array}{l}\text { It is a mutually beneficial BTA within South Asian region to expand } \\
\text { trade in goods and services between two parties. It is committed to } \\
\text { create duty free market access on } 206 \text { Sri Lankan products in } \\
\text { Pakistani market including tea, rubber and coconut. } \\
\text { Pakistan also gains duty free access on } 102 \text { products in the Sri Lankan }\end{array}$ \\
\hline
\end{tabular}




\begin{tabular}{|c|c|c|c|c|c|c|}
\hline & & & & & & $\begin{array}{l}\text { market which mainly include oranges, basmati rice and engineering } \\
\text { goods. Pakistan negative list consists of } 540 \text { products imported from } \\
\text { Sri Lanka and Sri Lanka also notified } 697 \text { of Pakistan products as } \\
\text { negative list. Sri Lanka has also granted Tariff Rate Quotas (RTQ) for } \\
6000 \mathrm{Mt} \text { of Basmati rice and } 1000 \mathrm{Mt} \text { of potatoes per year on duty- } \\
\text { free basis through the agreement. Import of potatoes is permitted only } \\
\text { during Sri Lanka's off season. The product import in excess to agreed } \\
\text { TRQ will be subjected to normal tariff applied by importing country. }\end{array}$ \\
\hline 06 & $\begin{array}{l}\text { India } \\
\text { Singapore }\end{array}$ & India, Singapore & 01-Aug-2005 & $\begin{array}{l}\text { FTA } \\
\text { and } \\
\text { EIA }\end{array}$ & $\begin{array}{l}\text { Goods } \\
\text { and } \\
\text { service }\end{array}$ & $\begin{array}{l}\text { BTA between East Asia and South Asia. It is a comprehensive } \\
\text { economic cooperation agreement which liberalizes and promotes trade } \\
\text { in goods and services. It facilitates and enhances economic integration } \\
\text { to form a bridge between India and ASEAN and serve as a pathfinder } \\
\text { for India-ASEAN FTA. India provides concessions under main } \\
\text { categories of (i) Early harvest program: duty free entry from 1-Aug- } \\
2005 \text {, (ii) Phased elimination in duty: Duties will be removed in } 5 \\
\text { stages and duty free entry from 1-April-2009, (iii) Phased reduction in } \\
\text { duty: Duties will be reduced in } 5 \text { stages and (iv) Excluded list: No } \\
\text { concessions. Singapore eliminates custom duties on all originating } \\
\text { goods of India. }\end{array}$ \\
\hline 07 & $\begin{array}{l}\text { South Asian } \\
\text { Free Trade } \\
\text { Agreement } \\
\text { (SAFTA) }\end{array}$ & $\begin{array}{l}\text { Bangladesh, } \\
\text { Bhutan, India, } \\
\text { Maldives, Nepal, } \\
\text { Pakistan, } \\
\text { Lanka }\end{array}$ & 01-Jan-2006 & FTA & Goods & $\begin{array}{l}\text { It eliminates trade barriers and facilitate cross border movement of } \\
\text { goods between contracting states. It consists with tariff, para-tariff, } \\
\text { non-tariff measures and direct trade measures. SAFTA reduces tariff } \\
\text { on products from non-least developed countries to } 20 \% \text { from existing } \\
\text { rates and for least developed economies to } 30 \% \text {. Sensitive list will be } \\
\text { negotiated by contracting states and it is subjected to maximum } \\
\text { ceiling price which was mutually agreed by members. Contracting } \\
\text { parties give special consideration to least developed countries in case } \\
\text { of anti-dumping measures and the requests from those countries for } \\
\text { technical assistance. It enhance sustainable exports form least } \\
\text { developed countries through long and medium-term contracts, buy- } \\
\text { back arrangements and state trading operations. }\end{array}$ \\
\hline 08 & India-Bhutan & India, Bhutan & 29-July-2006 & FTA & Goods & Promote free trade and commerce between two countries. Both \\
\hline
\end{tabular}




\begin{tabular}{|c|c|c|c|c|c|c|}
\hline & $\begin{array}{l}\text { Free Trade } \\
\text { Agreement }\end{array}$ & & & & & $\begin{array}{l}\text { countries impose non-tariff restrictions on imports of third countries. } \\
\text { However Bhutan imposes non-tariff restrictions on imports of certain } \\
\text { Indian origin goods. New agreement provides movement of Bhutanese } \\
\text { goods from one part of Bhutan to another part of Bhutan through } \\
\text { India. India provides } 16 \text { entry/exit points for trade. }\end{array}$ \\
\hline 09 & India-Chile & India, Chile & 17-Aug-2007 & PSA & Goods & $\begin{array}{l}\text { A BTA between South America and South Asia to promote economic } \\
\text { cooperation between India and Chile. India provides fixed tariff } \\
\text { preferences from } 10 \% \text { to } 50 \% \text { for } 178 \text { products from Chile including } \\
\text { meat, fish, rock salt, chemicals and leather products. Chile provides } \\
\text { tariff preferences on } 296 \text { Indian products consists of chemicals, } \\
\text { pharmaceuticals, dyes and resins, plastic, rubber, textiles and clothing } \\
\text { with margin of preference from } 10 \% \text { to } 100 \% \text {. }\end{array}$ \\
\hline 10 & $\begin{array}{l}\text { Pakistan- } \\
\text { China }\end{array}$ & China, Pakistan & $\begin{array}{l}\text { Goods: } \\
\text { 01-July- } \\
2007 \\
\text { Service: } \\
\text { 10-Oct-2009 }\end{array}$ & $\begin{array}{l}\text { FTA } \\
\text { and } \\
\text { EIA }\end{array}$ & $\begin{array}{l}\text { Goods } \\
\text { and } \\
\text { services }\end{array}$ & $\begin{array}{l}\text { The agreement is committed to promote reciprocal trade and evasion } \\
\text { of trade barriers between two countries. It also strengthens the } \\
\text { friendship between two parties and encourages expansion and } \\
\text { diversification of trade between them. It eliminates import custom } \\
\text { duties on products from both countries under the categories of; (i) } \\
\text { Category I: Tariff will be eliminated in four stages as by } 25 \% \text {, } 50 \% \text {, } \\
75 \% \text { and } 100 \% \text { respectively, (ii) Category II: Tariff will be reduced to } \\
\text { below 5\% in five years, (iii) Category III: Tariff will be reduced to } \\
50 \% \text { by five years, (iv) Category IV: import duties will be reduced to } \\
20 \% \text { by five years and (v) Category V: no concessions. }\end{array}$ \\
\hline 11 & $\begin{array}{l}\text { Pakistan- } \\
\text { Malaysia }\end{array}$ & $\begin{array}{l}\text { Malaysia, } \\
\text { Pakistan }\end{array}$ & 01-Jan-2008 & $\begin{array}{l}\text { FTA } \\
\text { and } \\
\text { EIA }\end{array}$ & $\begin{array}{l}\text { Goods } \\
\text { and } \\
\text { services }\end{array}$ & $\begin{array}{l}\text { BTA between East Asia and South Asia. It is the } 1^{\text {st }} \text { BTA between two } \\
\text { Muslim countries and also Malaysia's } 1^{\text {st }} \text { BTA with a South Asian } \\
\text { country. Pakistan eliminated tariff on } 43.2 \% \text { imports from Malaysia } \\
\text { and on the other hand Malaysia eliminated tariff on } 78 \% \text { of imports } \\
\text { from Pakistan. Malaysia provided market access to Pakistan in the } \\
\text { field of computer; IT related services, Islamic Banking and Islamic } \\
\text { insurance. The agreement also promotes investments to facilitate }\end{array}$ \\
\hline
\end{tabular}




\begin{tabular}{|c|c|c|c|c|c|c|}
\hline & & & & & & entrepreneurs of both countries. \\
\hline 12 & $\begin{array}{l}\text { MERCOSUR } \\
\text { - India }\end{array}$ & $\begin{array}{l}\text { Argentina, Brazil, } \\
\text { Paraguay, } \\
\text { Uruguay, India }\end{array}$ & $\begin{array}{l}\text { 01-June- } \\
2009\end{array}$ & PSA & Goods & $\begin{array}{l}\text { BTA between South America and South Asia. One party is an RTA. It } \\
\text { expands and strengthens the existing relations between MERCOSUR } \\
\text { and India and promotes trade by granting reciprocal fixed tariff } \\
\text { preferences. MERCOSUR member states provide concessions on } 452 \\
\text { Indian products which covered food preparations, organic chemicals, } \\
\text { pharmaceuticals, essential oils, plastic, rubber product and machinery } \\
\text { items. India provide concessions on } 450 \text { MERCOSUR's item } \\
\text { including meat products, organic and inorganic chemicals, dyes, raw } \\
\text { hides, skins, leather, wool, cotton, glassware and steel. }\end{array}$ \\
\hline 13 & India- Nepal & India, Nepal & 27-Oct-2009 & PSA & Goods & $\begin{array}{l}\text { Undertake all measures, including technical cooperation, to promote, } \\
\text { facilitate, expand and diversify trade between their two countries. } \\
\text { India agrees to promote industrial development of Nepal through } \\
\text { grants on the basis of non reciprocity specially the imports to India } \\
\text { which subject to custom duties and quantitative restrictions. Positive } \\
\text { list (fixed quota basis): Vegetable fats (Vanaspati), Acrylic Yam, } \\
\text { Copper products, Zinc Oxide Negative list: Alcoholic Beverages, } \\
\text { perfumes and cosmetics with non Nepalese/Non Indian brand name, } \\
\text { Cigarette and tobacco. }\end{array}$ \\
\hline 14 & $\begin{array}{l}\text { Korea, } \\
\text { Republic of } \\
\text { India }\end{array}$ & India, Korea & 01-Jan-2010 & $\begin{array}{l}\text { FTA } \\
\text { and } \\
\text { EIA }\end{array}$ & $\begin{array}{l}\text { Goods } \\
\text { and } \\
\text { service }\end{array}$ & $\begin{array}{l}\text { It liberalizes and facilitates trade in goods and services and expands } \\
\text { investment between two countries. Concessions through the } \\
\text { agreement are subjected to following product categories;(i) E-0: Duty- } \\
\text { free, (ii) E-5: Tariff will be removed in five equal annual stages, (iii) } \\
\text { E-8: Tariff will be removed in } 8 \text { equal annual stages, (iv) RED: Tariff } \\
\text { will be reduced to } 1 \% \text { to } 5 \% \text { from the base rate in } 8 \text { equal annual } \\
\text { stages, (v) SEN: Tariff will be reduced by } 50 \% \text { in ten equal annual } \\
\text { stages for India, and for Korea, it is by } 50 \% \text { in } 8 \text { equal annual stages } \\
\text { (vi) EXC: No concessions }\end{array}$ \\
\hline 15 & ASEAN-India & $\begin{array}{l}\text { East Asia, West } \\
\text { Asia (Myanmar, } \\
\text { Brunei, }\end{array}$ & 01-Jan-2010 & FTA & Goods & $\begin{array}{l}\text { A BTA between East Asia and South Asia. One party is an RTA. It is } \\
\text { committed to establish ASEAN-India Free Trade Area and provide } \\
\text { special and differential treatment to ensure the increasing participation }\end{array}$ \\
\hline
\end{tabular}




\begin{tabular}{|c|c|c|c|c|c|c|}
\hline & & $\begin{array}{l}\text { Cambodia, } \\
\text { Indonesia, Lao, } \\
\text { Malaysia, } \\
\text { Philippine, } \\
\text { Singapore, } \\
\text { Vietnam, } \\
\text { Thailand, India) }\end{array}$ & & & & $\begin{array}{l}\text { of new ASEAN members in economic integration and cooperation } \\
\text { activities. Tariff reduction through the agreement are subjected to } \\
\text { main five tracks ;(i) Normal Track: MFN tariff remains at zero } \\
\text { percent (ii) Sensitive Track: MFN tariff above } 5 \text { percent will be } \\
\text { reduced to } 5 \text { percent (iii) Special Product (iv) Highly Sensitive list (v) } \\
\text { Exclusion list }\end{array}$ \\
\hline 16 & $\begin{array}{l}\text { India- } \\
\text { Malaysia }\end{array}$ & India, Malaysia & 01-Jul-2011 & $\begin{array}{l}\text { FTA } \\
\text { and } \\
\text { EIA }\end{array}$ & $\begin{array}{l}\text { Goods } \\
\text { and } \\
\text { service }\end{array}$ & $\begin{array}{l}\text { Bilateral Trade Agreement between East Asia and South Asia. It was } \\
\text { a Comprehensive Economic Cooperation Agreement to enhance } \\
\text { economic and social benefit, improving living standards and ensure } \\
\text { high and steady in real incomes through expansion of trade and } \\
\text { investment flows. Both parties do not maintain non-tariff measures on } \\
\text { other party. Tariff lines are subjected to tariff reduction and } \\
\text { subsequent eliminations under the main categories of (i) Normal track: } \\
\text { MFN tariff remains at zero percent (ii) Sensitive track: MFN tariff } \\
\text { above } 5 \text { percent will be reduced to } 5 \text { percent (iii) Special products: } \\
\text { MFN tariff are lower than the preferential tariff (iv) Highly sensitive } \\
\text { list: reduction of MFN tariff to } 50 \% \text { or by } 50 \% \text { or by } 25 \% \text { (v) Special } \\
\text { track: as per the schedule and (v) Exclusion list: subject to annual } \\
\text { tariff reviews }\end{array}$ \\
\hline 17 & India- Japan & India, Japan & 01-Aug-2011 & $\begin{array}{l}\text { FTA } \\
\text { and } \\
\text { EIA }\end{array}$ & $\begin{array}{l}\text { Goods } \\
\text { and } \\
\text { service }\end{array}$ & $\begin{array}{l}\text { No quantitative restrictions or import prohibition. All parties should } \\
\text { not introduce any restrictions other than custom duty imports or } \\
\text { exports to the other party if it is inconsistent with WTO. India positive } \\
\text { list: Petroleum products, Diamonds, Light oils, cathodes, organic } \\
\text { compounds, rice, cotton, clothes, shrimps and vehicle parts. Positive } \\
\text { list of Japan: Gear box, Cylinders, Digital Camera, Television, } \\
\text { Processors, Photosensitive devices, chemical elements. }\end{array}$ \\
\hline
\end{tabular}

Source: World Trade Organization 


\section{ANNEX 02}

This section consists with the addition table related to gravity model estimation.

Table 1. VIF values of variables used in Gravity Model Estimation

\begin{tabular}{lcccc}
\hline & \multicolumn{2}{c}{ World exports } & \multicolumn{2}{c}{ South Asian exports } \\
\cline { 2 - 5 } & Without F.E. & With F.E. & Without F.E. & With F.E. \\
\hline ln exporter GDP & 1.04 & & 1.12 & \\
ln importer GDP & 1.09 & & 1.11 & \\
ln distance & 1.41 & 2.51 & 1.30 & 9.52 \\
Common language & 1.08 & 1.78 & 1.09 & 2.50 \\
Common colony & 1.07 & 1.24 & 1.04 & 10.95 \\
WTO & 1.09 & 18.67 & 1.17 & 77.53 \\
RTA & 1.43 & 1.93 & 1.26 & 3.97 \\
BTA & 1.02 & 1.24 & 1.20 & 1.66 \\
\hline
\end{tabular}

Following table shows the effects on individual countries if it controls the multilateral resistance of country pairs by using exporter and importer fixed effects in the model.

Table 2. Fixed effects estimation of Gravity Model Estimation on the Effects of different RTAs and BTAs on Trade Flows

\begin{tabular}{|c|c|c|}
\hline \multirow[t]{2}{*}{ Country } & \multicolumn{2}{|c|}{ World total exports } \\
\hline & Coefficient & S.D. \\
\hline Australia & $2.26^{* *}$ & 0.76 \\
\hline Azerbaijan & $2.29 * *$ & 0.75 \\
\hline Belgium & $4.76 * * *$ & 0.67 \\
\hline Brazil & $3.76^{* * *}$ & 0.72 \\
\hline Canada & $1.43 *$ & 0.75 \\
\hline China & $8.26 * * *$ & 0.65 \\
\hline Czech Republic & $7.05 * * *$ & 0.64 \\
\hline Finland & $6.97 * * *$ & 0.81 \\
\hline Georgia & $8.25 * * *$ & 0.64 \\
\hline Germany & $9.41 * * *$ & 0.64 \\
\hline Hong Kong China & $8.68 * * *$ & 0.64 \\
\hline Hungary & $8.73 * * *$ & 0.83 \\
\hline Iceland & $7.75 * * *$ & 0.65 \\
\hline India & $7.09 * * *$ & 0.64 \\
\hline Indonesia & $8.66 * * *$ & 0.64 \\
\hline Japan & $7.85 * * *$ & 0.64 \\
\hline Kazakhstan & $5.65 * * *$ & 0.65 \\
\hline Luxembourg & $10.63 * * *$ & 0.64 \\
\hline Macao & $10.25 * * *$ & 0.63 \\
\hline Malaysia & $10.43 * * *$ & 0.64 \\
\hline Maldives & $8.96 * * *$ & 0.64 \\
\hline Mexico & $10.05^{* * *} *$ & 0.65 \\
\hline Netherland & $9.03 * * *$ & 0.65 \\
\hline New Zealand & $9.61 * * *$ & 0.64 \\
\hline Pakistan & $10.51 * * *$ & 0.63 \\
\hline
\end{tabular}


Philippine

Poland

Portugal

Russian Federation

Samoa

Singapore

Slovak Republic

South Africa

Spain

Sri Lanka

Switzerland

Thailand

Turkey

United Kingdom

United States

$\begin{array}{cc}9.14 * * * & 0.65 \\ 10.12 * * * & 0.64 \\ 9.10^{* * *} & 0.64 \\ 10.08 * * * & 0.63 \\ 10.65 * * * & 0.63 \\ 10.14 * * * & 0.63 \\ 10.16 * * * & 0.62 \\ 11.43 * * * & 0.77 \\ 10.10^{* * *} & 0.67 \\ 10.54 * * * & 0.63 \\ 10.78 * * * & 0.63 \\ 11.68 * * * & 0.63 \\ 11.78 * * * & 0.63 \\ 13.05 * * * & 0.63 \\ 12.57 * * * & 0.62\end{array}$

$9.14 * * *$

65

0.64

0.63

0.63

0.63

0.77

0.67

0.63

0.63

0.63

0.63

0.62

*** Significant at 0.001 probability level

** Significant at 0.05 probability level

* Significant at 0.1 probability level

\section{ANNEX 03}

A map depicting various RTAs and BTAs in South Asia

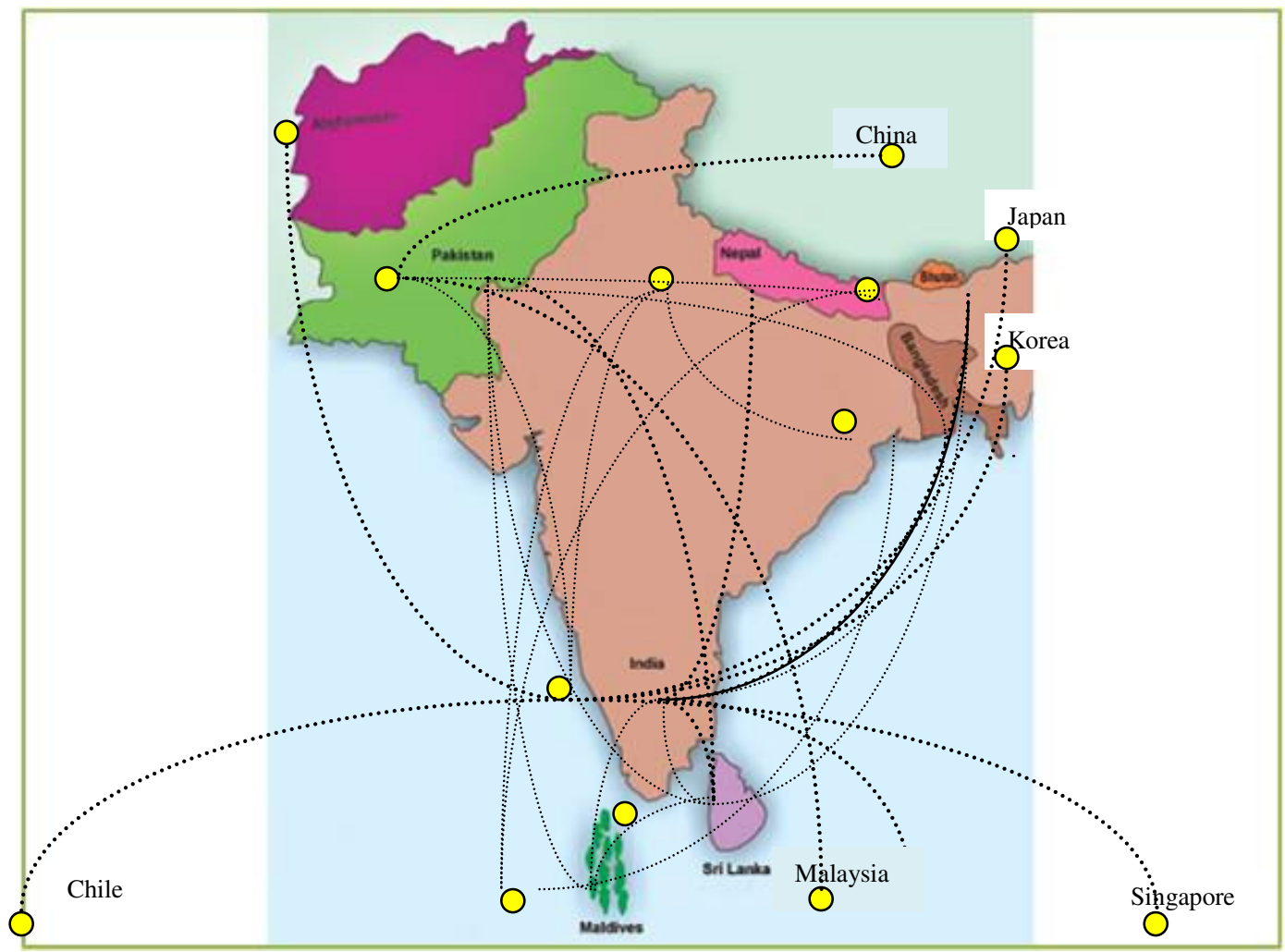

Source: World Trade Organization 